\title{
Rancang Bangun Mesin Pengolah Jagung Untuk Pakan Ternak
}

\author{
Taufik kurniawan Mansur ${ }^{1}$, Muh. Zultan², Hanasia ${ }^{3}$, Abdul Salam ${ }^{4 *}$ Luther Sonda $^{5}$ \\ 1,2,3,4,5 Jurusan Teknik Mesin, Politeknik Negeri Ujung Pandang, Makassar 90245, Indonesia \\ email: abdsalam@poliupg.ac.id
}

\begin{abstract}
Begin from the people who process corn traditionally, which have very difficulty in processing for animal feed, besides that there are some parts of the corn that still become waste, these problems can be solved by using a multipurpose corn processor. The manufacture of this tool is carried out to simplify and speed up processing of corn by utilizing all parts of the corn starting from stems and weevils for cow feed and corn kernels for chicken feed. Method used are designing, assembling, manufacturing, and testing the process by testing the materials based on 3 types of engine speed, capacity (minutes) to obtain optimal conditions from the performance of the tools that have been made. Based on the test results, it can be obtained the percentage of processing, namely corn kernels of $80 \%$ (Ø3 mm (1 kg / 4 minutes), $\varnothing 6 \mathrm{~mm}(1 \mathrm{~kg} / 8$ minutes)), $50 \%$ corncobs (1 kg / 8 minutes), corn stalks / $80 \%$ grass $(1 \mathrm{~kg} / \mathrm{min})$
\end{abstract}

Keywords: processing machines, corn, corn kernels, corncob, corn stalks, animal feed.

\begin{abstract}
Abstrak: Bermula dari masyarakat yang mengolah jagung secara tradisional yang sangat kesulitan dalam pengolahannya sebagai pakan ternak, selain itu ada beberapa bagian jagung yang masih menjadi limbah, masalah ini dapat diatasi dengan menggunakan alat pengolah jagung serbaguna sebagai solusinya. Pembuatan alat ini dilakukan untuk mempermudah dan mempercepat pengolahan pada jagung dengan memanfaatkan seluruh bagian dari jagung tersebut mulai dari batang dan bonggol untuk pakan sapi serta biji jagung untuk pakan ayam,sehubungan dengan itu metode yang digunakan ialah proses perancangan, perakitan, dan pembuatan, kemudian di lanjutkan ke proses pengujian dengan menguji bahan-bahan berdasarkan 3 jenis putaran mesin, kapasitas (menit) untuk memperoleh kondisi optimal dari hasil kinerja alat yang telah dibuat. Berdasarkan hasil pengujian maka dapat diperoleh persentase pengolahan yaitu pada biji jagung sebesar $80 \%\{\varnothing 3$

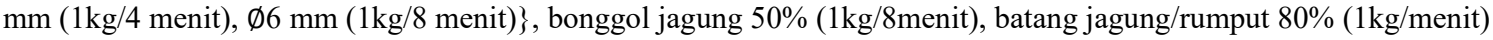

Kata kunci : mesin pengolah, jagung, biji jagung, bonggol jagung, batang jagung, pakan ternak.

\section{PENDAHULUAN}

Indonesia merupakan salah satu negara agraris, dimana jagung merupakan komoditas tanaman pangan yang banyak dikembangkan oleh para petani, karena jagung merupakan tanaman pangan terpenting kedua setelah padi. Selain itu jagung juga merupakan salah satu pangan strategis yang bernilai ekonomi karena kedudukannya sebagai salah satu sumber karbohidrat. Pemanfaatan jagung selain sebagai bahan subtitusi beras juga dapat digunakan untuk pakan ternak dan bukan hanya biji jagung yang dapat di olah menjadi pakan ternak tetapi batang beserta bonggol yang merupakan limbah pertanian bisa diolah menjadi pakan ternak.

Usaha pengembangan peternakan perlu didukung dengan ketersediaan pakan yang berkualitas dalam jumlah yang cukup sepanjang tahun. Namun demikian sampai saat ini meskipun sudah ada produksi pakan komersial (konsentrat) tetapi jumlahnya masih terbatas dan susah di jangkau masyarakat yang kemudian masih menjadi kendala utama, sehingga perlu mencari alternatif pengolah pakan ternak yang bisa di jangkau masyarakat.

Berdasarkan hasil wawancara salah satu warga (Muttiara) tepatnya di Kabupaten Pangkep Kelurahan Balocci yang merupakan seorang penghasil jagung dan peternak sapi, ujarnya " Sebagian petani dikampung kami masih kesulitan dalam pengolahan hasil pertanian khususnya tanaman jagung, karena alat pengolahan jagung yang susah di jangkau masyarakat, olehnya itu memilih masih menggunakan proses tradisional dalam pengolahan jagung yang membutuhkan waktu cukup lama yaitu $5 \mathrm{~kg} / \mathrm{jam}$, dan untuk batang jagung yang keras, tidak bisa di konsumsi oleh sapi”. 
Untuk dapat melaksanakan penanganan pada pengolahan tanaman jagung yang tepat dibutuhkan alat yang efektif yang didasarkan pada prinsip-prinsip yang benar. Salah satu teknologi tepat guna dalam penanganan pasca panen adalah mesin pengolah jagung untuk pakan ternak.

Mesin pengolah jagung untuk pakan ternak ini dapat berfungsi sebagai pemecah biji jagung untuk pakan ternak ayam, pencacah batang jagung untuk pakan ternak sapi, dan penghancur bonggol jagung untuk campuran pakan ternak sapi. Mesin ini bertujuan untuk memudahkan proses pengolahan jagung untuk menghasilkan pakan ternak ayam dan bahan pakan ternak sapi pada mesin pengolah jagung untuk pakan ternak, serta meningkatkan kualitas bahan pakan ternak.

\section{A. Tanaman Jagung}

Tanaman jagung (Zea Mays L) diduga berasal dari Meksiko Selatan kemudian menyebar keseluruh dunia. Di Indonesia daerah-daerah penghasil jagung adalah Jawa Barat, Jawa Tengah, Jawa Timur, Madura, D.I. Yogyakarta, NTT, Sulawesi Utara, Gorontalo, Sulawesi Selatan, dan Maluku [1]. Jagung merupakan tanaman penghasil pakan yang paling penting, terutama untuk menghasilkan biji. Biji jagung sering disebut the king of cereal dan merupakan bahan pakan yang baik untuk semua jenis ternak. Jagung banyak digunakan untuk pakan ternak unggas sebagai sumber utama energi.

Penggunaan biji jagung sebagai pakan ternak tidak ada pembatasannya yang disebabkan oleh kandungan zat anti nutrisinya. Sebagai komponen utama dalam ransum, kualitas yang sangat berpengaruh terhadap kualitas ransum secara keseluruhan dan pada akhirnya akan berpengaruh terhadap performan ternak yang mengkonsumsinya[2].

Selain biji jagung, bonggol jagung juga dapat dijadikan sebagai pakan ternak sapi, dimana biasanya bonggol jagung yang telah melewati proses pemipilan hanya dibuang saja, atau biasanya digunakan sebagai bahan bakar dapur ataupun pengasapan untuk pengusir nyamuk pada kandang ternak.

Jerami jagung merupakan limbah pertanian. Kebanyakan petani hanya membiarkan jerami jagung kering, namun jerami jagung tersebut memiliki manfaat yang besar bagi hewan sebagai pakan ternak utamanya pada sapi. Jerami jagung merupakan sisa dari tanaman jagung setelah buahnya dipanen dikurangi akar dan sebagian batang yang tersisa. Pemanfaatan jerami jagung adalah sebagai pakan ternak sapi [3].

\section{B. Mesin Pengolah Jagung Untuk Pakan Ternak}

Mesin pengolah jagung untuk pakan ternak memudahkan manusia dalam mengolah jagung untuk dimanfaatkan sebagai pakan ternak. Pengertian mesin pengolah jagung untuk pakan ternak jarang ditemukan, sehingga cukup sulit untuk menjelaskan pengertian mesin pengolah jagung untuk pakan ternak ini secara keseluruhan. Oleh karena itu, pengertian mesin pengolah jagung untuk pakan ternak harus didefenisikan perkata. Mesin merupakan peralatan yang digerakkan oleh suatu kekuatan/tenaga yang dipergunakan untuk membantu manusia dalam mengerjakan produk atau bagian-bagian produk tertentu [4]. Pengolah yaitu Mesin yang digunakan untuk mengolah [5].

\section{A. Dasar-Dasar Rancang Bangun Mesin Pengolah Jagung Untuk Pakan Ternak}

\section{Daya Motor}

$$
P=\frac{2 \cdot \pi \cdot n \cdot T}{60}
$$

$$
\begin{array}{ll}
\text { Keterangan: } & \mathrm{P}=\text { daya yang dibutuhkan }(\mathrm{kw}) \\
& \mathrm{T}=\text { Torsi }(\mathrm{Nmm}) \\
& \mathrm{N}=\text { Kecepatan putar }
\end{array}
$$

Dimana

$$
T=F \cdot R
$$

$$
\text { Keterangan: } \quad \mathrm{F}=\text { Gaya Putar }(\mathrm{N})
$$


204 Rancang Bangun Mesin Pengolah Jagung Untuk Pakan Ternak. Taufik kurniawan Mansur, Muh. Zultan, Hanasia, Abdul Salam, Luther Sonda

$$
\mathrm{R}=\text { Jarak pisau dari titik pusat }(\mathrm{mm})
$$

Daya rencana pada motor sebagai berikut:

$$
\mathrm{Pd}=\mathrm{P} \times \mathrm{fc}
$$

Keterangan: $\quad \mathrm{Pd}=$ daya rencana

$$
\mathrm{Fc}=\text { faktor koreksi }
$$

\section{Poros}

Untuk menentukan dimensi poros yang mendapatkan momen puntir dan momen bengkok[6] sebagai berikut:

$$
\begin{aligned}
& \text { Keterangan: } \quad \text { Ds }=\text { diameter poros }(\mathrm{mm}) \\
& \mathrm{T} \quad=\text { momen puntir }(\mathrm{kg} / \mathrm{mm}) \\
& \tau_{\alpha} \quad=\text { tegangan geser izin }(\mathrm{kg} / \mathrm{mm}) \\
& \mathrm{Kt}=\text { harga faktor momen puntir } \\
& C_{b} \quad=\text { harga faktor beban lentur }
\end{aligned}
$$

Besarnya momen puntir yang terjadi pada poros dapat ditentukan dengan menggunakan persamaan sebagai berikut:

$$
T=9.74 \times 10^{5} \frac{P_{d}}{n_{2}}
$$

Keterangan: $\quad \mathrm{Pd} \quad=$ daya $\operatorname{rencana}(\mathrm{Kw})$

$$
\mathrm{n}_{2} \quad=\text { putaran poros }(\mathrm{rpm})
$$

\section{Sabuk}

$$
\begin{array}{ccl}
\mathbf{L}=\boldsymbol{\pi}\left(\boldsymbol{r}_{\mathbf{1}}+\boldsymbol{r}_{\mathbf{2}}\right) & +\mathbf{2} \boldsymbol{x}+\frac{(\boldsymbol{r}-\boldsymbol{r})^{2}}{\boldsymbol{x}} \\
\text { Dimana : } & \mathrm{L} & =\text { Panjang sabuk }(\mathrm{mm}) \\
& r_{1} & =\text { Jari-jari puli yang digerakkan }(\mathrm{mm}) \\
r_{2} & =\text { Jari-jari puli pada motor }(\mathrm{mm}) \\
x & =\text { Jarak sumbu kedua puli }(\mathrm{mm})
\end{array}
$$

\section{Perhitungan Puli}

$$
\frac{N_{2}}{N_{1}}=\frac{D_{1}}{D_{2}}
$$

Dimana:

$$
\begin{array}{ll}
\mathrm{D}_{1} & =\text { Diameter Puli Motor }(\mathrm{mm}) \\
\mathrm{D}_{2} & =\text { Diameter Puli Poros }(\mathrm{mm}) \\
\mathrm{N}_{1} & =\text { Putaran Puli Penggerak }(\mathrm{rpm}) \\
\mathrm{N}_{2} & =\text { Putaran Puli poros transmisi (rpm) }
\end{array}
$$

\section{Kekuatan Las}

$$
\begin{array}{lll} 
& & A=0.707 \cdot h \cdot l \\
\text { Dimana: } & A & =\text { Luas Pengelasan }(\mathrm{mm}) \\
& h & =\text { Tebal Pengelasan }(\mathrm{mm}) \\
& l & =\text { Panjang Pengelasan }(\mathrm{mm})
\end{array}
$$

Sehingga didapatkan:

$$
\sigma t=\frac{F}{0.707 \cdot h \cdot l}
$$




\section{METODOLOGI PENELITIAN}

Dalam melaksanakan penelitian ini, penulis melakukan beberapa metode yaitu perancangan, pembuatan, dan pengujian.

\section{A. Perancangan}

Pada tahapan ini penulis melakukan perhitungan dan desain gambar mesin.

\section{Perhitungan Rancang Bangun}

\section{a. Perhitungan Daya Motor}

Untuk menentukan daya motor digunakan perhitungan sebagai berikut:

Dik: Bobot beban

$$
F=m \cdot g
$$

$$
\begin{array}{ll}
\text { Poros } & =1,4 \mathrm{~kg}(\text { Simulasi Fushion) } \\
\text { Mata Pisau }=250 \mathrm{gr} \times 3=750 \mathrm{gr}=0,75 \mathrm{~kg} \text { (Simulasi Fushion) } & \\
\text { Piringan Mata Pisau } & =8,9 \mathrm{~kg} \text { (Simulasi Fushion) } \\
\text { Hammer } & =217 \mathrm{gr} \times 16=3,472 \mathrm{~kg} \text { (Simulasi) } \\
\text { Piringan Hammer } & =2,11 \mathrm{~kg} \text { (Simulasi Fushion) Lihat } \\
\text { Baut poros Hammer } & =174 \mathrm{gr} \times 4=0,696 \mathrm{~kg} \text { (Simulasi) } \\
\text { Bobot total } & =1,9+078+5+3,52+3+0,8=15 \mathrm{~kg}
\end{array}
$$

Diperoleh: $\quad \mathrm{m} \quad=17,328 \mathrm{Kg}$

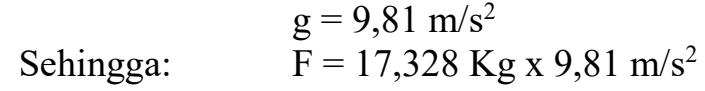

$$
\begin{aligned}
& \mathrm{F}=17,328 \mathrm{Kg} \times 9,81 \mathrm{~m} / \mathrm{s}^{2} \\
& \mathrm{~F}=169,99 \mathrm{~N}
\end{aligned}
$$

Berdasarkan pengujian awal, putaran mesin yang paling sesuai untuk mesin pengolah jagung berkisar antara $2.000-2.400 \mathrm{rpm}$. Oleh karna itu, diambil kecepatan putar sedang $2200 \mathrm{rpm}$ Sedangkan untuk putaran yang dihasilkan pada puli yang digerakkan sebesar:

$$
\frac{n_{1}}{n_{2}}=\mathrm{i}
$$

Dimana: $\quad \mathrm{n}_{1}=$ Putaran motor penggerak yang direncanakan $(2.200 \mathrm{rpm})$

$\mathrm{n}_{2}=$ Putaran yang digerakkan

$\mathrm{i}=$ Putaran reduksi yang direncanakan

$$
\begin{aligned}
& \frac{2.200}{n_{2}}=2,2 \\
& \mathrm{n}_{2}=\frac{2.200}{2,2} \\
& \mathrm{n}_{2}=1.000 \mathrm{rpm}
\end{aligned}
$$

Sehingga didapatkan putaran sebesar $1.000 \mathrm{rpm}$

Perhitungan daya motor Bensin yang digunakan persamaan:

$$
\begin{aligned}
T & =F \cdot R \\
& =169,99 \mathrm{~N} \times 0,083 \mathrm{~m} \\
& =14,10 \mathrm{Nm}
\end{aligned}
$$

Sehingga: $\quad P=\frac{2 \cdot \pi \cdot n \cdot T}{60}$

$$
\begin{aligned}
& P=\frac{T(2 \cdot \pi \cdot 1.000)}{60} \\
& P=\frac{14,10(2 \cdot 3,14 \cdot 1.000)}{60} \\
& \mathrm{P}=1.475,8 \mathrm{watt}
\end{aligned}
$$

Untuk mengantisipasi adanya beban lebih, maka dikalikan faktor koreksi $\mathrm{f}_{\mathrm{c}}$

$$
\begin{aligned}
\mathrm{f}_{\mathrm{c}} & =2.0 \\
\mathrm{P}_{\mathrm{d}} & =\mathrm{f}_{\mathrm{c}} \times \mathrm{P} \\
& =2,0 \times 1.277,981.475,8 \\
& =2.951,6 \mathrm{Watt}
\end{aligned}
$$


206 Rancang Bangun Mesin Pengolah Jagung Untuk Pakan Ternak. Taufik kurniawan Mansur, Muh. Zultan, Hanasia, Abdul Salam, Luther Sonda

$$
\begin{aligned}
& =3,958 \mathrm{Hp} \\
& =3,9 \mathrm{Hp}
\end{aligned}
$$

Untuk memenuhi pengembangan rancangan mesin kedepannya dan mempertimbangkan faktor keamanan, maka dipilih mesin penggerak bensin dengan daya 5.5 hp (stater tarik).

\section{b. Perhitungan Poros}

\section{Menentukan Momen Puntir}

Untuk mengetahui momen puntir yang terjadi pada poros penekan digunakan persamaan sebagai berikut:

$$
T=9.74 \times 10^{5} \frac{P_{d}}{n_{1}}
$$

$$
\begin{array}{cc}
\text { Dimana: } & \mathrm{T}=\text { Momen puntir }(\mathrm{kg} / \mathrm{mm}) \\
\mathrm{P}_{\mathrm{d}}=3,958 \mathrm{HP} \\
\mathrm{n}=\text { Putaran pisau }(\mathrm{rpm}) \\
\frac{N_{2}}{N_{1}}=\frac{D_{1}}{D_{2}} \\
N 2=\frac{N_{1} \cdot D_{1}}{D_{2}} \\
=\frac{2.200 \cdot 63,5}{139,7} \\
=1.000 \mathrm{rpm} \\
\text { maka: } \quad \mathrm{T}=9.74 \times 10^{5} \frac{3,958}{1.000} \\
=3.855,1 \mathrm{~kg} / \mathrm{mm}
\end{array}
$$

\section{Menentukan Tegangan Geser yang diizinkan} berikut:

Tegangan geser yang diizinkan pada poros dapat diketahui dengan rumus

Dimana: $\tau_{\alpha}=$ Tegangan geser yang diizinkan $\left(\mathrm{kg} / \mathrm{mm}^{2}\right)$

$\sigma_{B}=$ Tegangan tarik bahan poros yang digunakan (S30C)

$=48 \mathrm{~kg} / \mathrm{mm}^{2}$ (Sularso dan Kiyokatsu,2008)(Lampiran 2)

$\mathrm{Sf}_{1}=$ Faktor koreksi untuk pengaruh massa dan baja paduan

$$
=6 \text { (Untuk bahan S30C) }
$$

$\mathrm{Sf}_{2}=$ Faktor koreksi untuk pengaruh kekerasan permukaan $\quad(1,3-3,0)$

$$
=3 \text { (Dipilih) }
$$

Maka: $\quad \tau_{\alpha}=48 /(6 \times 3)=2.67 \mathrm{~kg} / \mathrm{mm}^{2}$

\section{Menentukan Diameter Poros}

$$
\mathrm{D}_{\mathrm{s}}=\left[\frac{5.1}{\tau_{\alpha}} K_{t} C_{b} T\right]^{1 / 3}
$$

Keterangan: $\quad$ Ds $\quad=$ Diameter poros $(\mathrm{mm})$

$$
\begin{aligned}
\mathrm{T} & =3.337,9 \mathrm{kgmm} 3.855,1 \\
\tau_{\alpha} & =2.67 \mathrm{~kg} / \mathrm{mm} \\
\mathrm{Kt} & =\text { Harga faktor momen puntir }(1.0-1.5) \\
& =1.5 \\
C_{b} \quad & =\text { Harga faktor beban lentur }(1.2-2.3) \\
& =1,5
\end{aligned}
$$

Maka:

$$
\mathrm{D}_{\mathrm{s}}=\left[\frac{5.1}{2,67} 1,5 \times 1,5 \times 3.855,1\right]^{1 / 3}
$$




$$
\begin{array}{ll}
\mathrm{D}_{\mathrm{s}} & =[16.480,55]^{1 / 3} \\
\mathrm{D}_{\mathrm{s}} & =25,4 \mathrm{~mm}
\end{array}
$$

Berdasarkan perhitungan di atas maka dipilih $\mathrm{Ds}=25,4 \mathrm{~mm}$

\section{c. Pemilihan Sabuk}

Sabuk yang digunakan jenis sabuk-V, dibandingkan dengan sistem transmisi rantai, sabuk-V mudah penangannya dan harganya pun murah.

Dimana: $X$ jarak sumbu antar poros $=580 \mathrm{~mm}$

$$
\mathrm{L}=\pi\left(r_{1}+r_{2}\right)+2 x+\frac{\left(r_{1}-r_{2}\right)^{2}}{x}
$$

$$
\begin{aligned}
& \mathrm{L}=3,14(31,75+63,5)+2(580)+\frac{(31,75-63,5)^{2}}{580} \\
& \mathrm{~L}=299,085+1.160+\frac{(1.008,063)}{580} \\
& \mathrm{~L}=299,085+1.160+1,739 \\
& \mathrm{~L}=1.460,824 \mathrm{~mm}=57
\end{aligned}
$$

Dengan demikian sabuk yang cocok untuk digunakan adalah sabuk A-57

\section{d. Perhitungan Puli}

Pada perencanaan ini, puli yang digunakan adalah puli dengan alur V. Diameter puli motor adalah 2,5 inch atau $63,5 \mathrm{~mm}$, putaran motor sebesar $2.200 \mathrm{rpm}$ dan putaran poros Pengolah jagung $1000 \mathrm{rpm}$. Untuk menentukan ukuran diameter puli poros pisau digunakan persamaan berikut:

$$
\begin{aligned}
& \frac{N_{2}}{N_{1}}=\frac{D_{1}}{D_{2}} \\
& D_{1} \cdot N_{1}=D_{2} \cdot N_{2} \\
& \quad D_{2}=\frac{D_{1} \cdot N_{1}}{N_{2}} \\
& =\frac{63,5 \cdot 2.200}{1000} \\
& =139,7 \mathrm{~mm} \\
& =5,5 \mathrm{inch}
\end{aligned}
$$

Jadi puli yang cocok digunakan adalah puli 6 inch sesuai yang tersedia dipasaran

\section{e. Kekuatan Las}

Dalam pembuatan alat ini, kami menggunakan las listrik dengan tebal plat 3 mm. Adapun bahan elektroda yang digunakan adalah AWS E.60, dengan 1 Psi = $6,894757 \mathrm{~N} / \mathrm{mm}^{2}$ dengan kekuatan tarik maksimum $62 \mathrm{~K}_{\mathrm{psi}}$ (Lampiran 6)

$$
\begin{aligned}
\sigma_{\mathrm{t} \max } & =62 \times 6,894757 \cdot 10^{-3} \\
& =427,47 \mathrm{MPa}
\end{aligned}
$$

Tegangan tarik izin elektroda dengan faktor keamanan $(\mathrm{v})=5$ dapat dihitung dengan persamaan:

$$
\begin{aligned}
\sigma_{\text {tizin }} & =\frac{\sigma_{t \max }}{v} \\
& =\frac{427,47}{5} \\
& =85,494 \mathrm{~N} / \mathrm{mm}^{2}
\end{aligned}
$$

Tegangan geser izin elektroda:

$$
\begin{aligned}
\sigma_{g} & =0.5 \times \sigma_{t} \\
& =0.5 \times 85,494 \\
& =42,474 \mathrm{~N} / \mathrm{mm}^{2}
\end{aligned}
$$

Luas penampang

$$
\begin{aligned}
A & =0,707 \cdot h \cdot l \\
& =0,707 \cdot 3 \cdot 40 \\
& =84,84 \mathrm{~mm}^{2}
\end{aligned}
$$


208 Rancang Bangun Mesin Pengolah Jagung Untuk Pakan Ternak. Taufik kurniawan Mansur, Muh. Zultan, Hanasia, Abdul Salam, Luther Sonda

$$
\text { Dengan } \begin{aligned}
\mathrm{m} & =16 \mathrm{~kg} \\
\mathrm{~g} & =9,8 \mathrm{~m} / \mathrm{s}^{2} \\
F & =m \cdot g \\
& =16 \cdot 9,8 \\
& =156,8 \mathrm{~N}
\end{aligned}
$$

Tegangan geser dapat dihitung dengan menggunakan rumus :

$$
\begin{aligned}
\sigma_{g} & =\frac{F}{A} \\
& =\frac{156,8}{84,84} \\
& =1,84 \mathrm{~N} / \mathrm{mm}^{2}
\end{aligned}
$$

Dari perhitungan di atas dapat disimpulkan bahwa pengelasan aman karena lebih kecil dari tegangan geser izin elektroda.

\section{Desain Gambar Mesin}

Desain gambar menggunakan software Autodesk Fusion 360. Hasil rancangan dapat dilihat pada Gambar 2.1

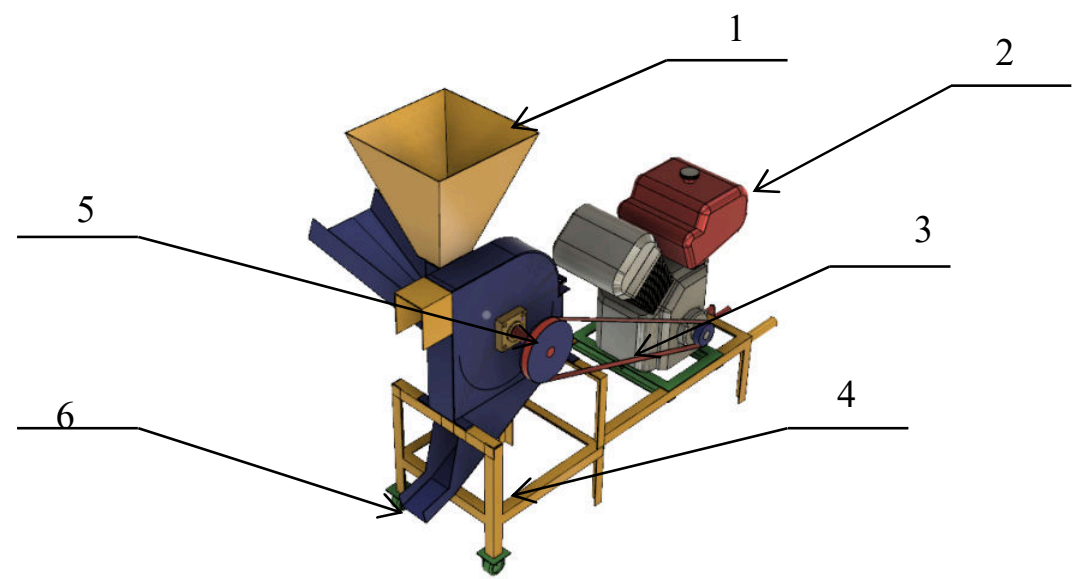

1. Corong

2. Motor Penggerak

3. Sabuk

4. Rangka

5. Pulley

6. Hopper

Gambar 2.1. Desain Rancangan Mesin Pengolah Jagung

Prinsip kerja mesin pengolah jagung untuk pakan ternak menggunakan motor bakar sebagai sumber penggerak dan ditransmisikan menggunakan sabuk $(v$-belt $)$ yang terhubung dengan puli penggerak dan puli yang digerakkan, sehingga poros dapat menghasilkan putaran dan memutar mata pisau yang terhubung pada poros tersebut. Poros yang berputar memiliki pisau pemotong dan hammer (penumbuk) yang akan memotong dan mencacah bahan (pakan ternak) hingga menjadi potongan-potongan kecil.

\section{B. Pembuatan}

Setelah melakukan desain rancangan mesin, tahap berikutnya adalah melakukan pembuatan mesin berdasarkan hasil rancangan. Hasil pembuatan mesin pengolah jagung dapat dilihat pada Gambar 2.2 


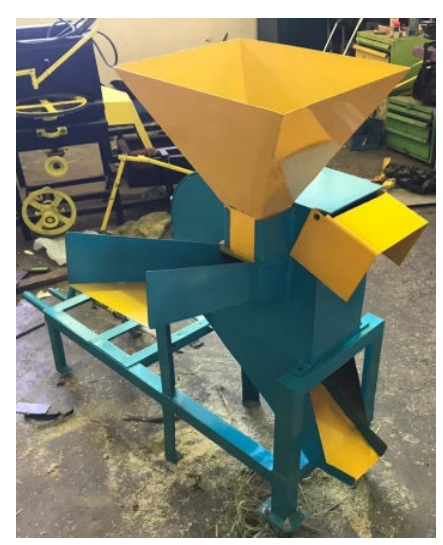

Gambar 2.2. Hasil Pembuatan Mesin Pengolah Jagung

\section{Pengujian Mesin}

Mesin yang telah dibuat, kemudian diuji untuk mengetahui hasil kinerja dari mesin tersebut. Variabel yang digunakan dalam pengujian adalah berat bahan, kecepatan, diameter saringan dan waktu olah. Keempat variabel tersebut ditetapkan pada tiap pengujian. Sedangkan variabel yang tidak tetap (dicari) adalah berat hasil olahan meliputi hasil kasar,halus, sisa dan yang terbuang. Tabel 1 sampai dengan Tabel 4 di bawah ini adalah hasil pengujian dari mesin

Tabel 1. Hasil pengujian biji jagung dengan diameter saringan $\emptyset 3 \mathrm{~mm}$

\begin{tabular}{|c|c|c|c|c|c|c|c|c|}
\hline \multirow[b]{2}{*}{ No } & \multirow{2}{*}{$\begin{array}{l}\text { Berat } \\
\text { Bahan }\end{array}$} & \multirow[b]{2}{*}{ Kecepatan } & \multirow{2}{*}{$\begin{array}{l}\text { Waktu } \\
\text { Olah }\end{array}$} & \multirow{2}{*}{$\begin{array}{l}\text { Hasil } \\
\text { Olah }\end{array}$} & \multicolumn{4}{|c|}{ Berat } \\
\hline & & & & & $\begin{array}{l}\text { Hasil } \\
\text { kasar }\end{array}$ & $\begin{array}{l}\text { Hasil } \\
\text { Halus }\end{array}$ & $\begin{array}{c}\text { Buang } \\
\text { Sisa }\end{array}$ & Terbuang \\
\hline 1 & $1000 \mathrm{gr}$ & 2000rpm & 8 menit & $930 \mathrm{gr}$ & $217 \mathrm{gr}$ & $243 \mathrm{gr}$ & $470 \mathrm{gr}$ & $70 \mathrm{gr}$ \\
\hline 2 & $1000 \mathrm{gr}$ & 2200rpm & 8 menit & $954 \mathrm{gr}$ & $309 \mathrm{gr}$ & $232 \mathrm{gr}$ & $413 \mathrm{gr}$ & $43 \mathrm{gr}$ \\
\hline 3 & $1000 \mathrm{gr}$ & 2400rpm & 8 menit & $964 \mathrm{gr}$ & $412 \mathrm{gr}$ & $327 \mathrm{gr}$ & $225 \mathrm{gr}$ & $36 \mathrm{gr}$ \\
\hline
\end{tabular}

Tabel 2. Hasil pengujian biji jagung dengan diameter saringan $\emptyset 6 \mathrm{~mm}$

\begin{tabular}{|c|c|c|c|c|c|c|c|}
\hline \multirow[b]{2}{*}{ No } & \multirow{2}{*}{$\begin{array}{l}\text { Berat } \\
\text { Bahan }\end{array}$} & \multirow[b]{2}{*}{ Kecepatan } & \multirow{2}{*}{$\begin{array}{c}\text { Waktu } \\
\text { Olah }\end{array}$} & \multirow{2}{*}{$\begin{array}{l}\text { Hasil } \\
\text { Olah }\end{array}$} & \multicolumn{3}{|c|}{ Berat } \\
\hline & & & & & $\begin{array}{l}\text { Hasil } \\
\text { kasar }\end{array}$ & $\begin{array}{l}\text { Hasil } \\
\text { Halus }\end{array}$ & $\begin{array}{c}\text { Hasil } \\
\text { Terbuang }\end{array}$ \\
\hline 1 & $1000 \mathrm{gr}$ & 2000rpm & 4 menit & $927 \mathrm{gr}$ & $791 \mathrm{gr}$ & $136 \mathrm{gr}$ & $73 \mathrm{gr}$ \\
\hline 2 & $1000 \mathrm{gr}$ & 2200rpm & 4 menit & $964 \mathrm{gr}$ & $837 \mathrm{gr}$ & $127 \mathrm{gr}$ & $36 \mathrm{gr}$ \\
\hline 3 & $1000 \mathrm{gr}$ & 2400rpm & 4 menit & $965 \mathrm{gr}$ & $831 \mathrm{gr}$ & $134 \mathrm{gr}$ & $35 \mathrm{gr}$ \\
\hline
\end{tabular}

Tabel 3. Hasil pengujian bonggol jagung

\begin{tabular}{|c|c|c|c|c|c|c|}
\hline \multirow{2}{*}{ No } & Berat & \multirow{2}{*}{ Kecepatan } & \multirow{2}{*}{$\begin{array}{c}\text { Waktu } \\
\text { Olah }\end{array}$} & $\begin{array}{c}\text { Berat } \\
\text { Basar }\end{array}$ & Berat Halus & Terbuang \\
\cline { 5 - 7 } & & & $660 \mathrm{gr}$ & $320 \mathrm{gr}$ & $20 \mathrm{gr}$ \\
\hline 1 & $1000 \mathrm{gr}$ & $2000 \mathrm{rpm}$ & 10 menit & $683 \mathrm{gr}$ & $40 \mathrm{gr}$ \\
\hline 2 & $1000 \mathrm{gr}$ & $2200 \mathrm{rpm}$ & 10 menit & $477 \mathrm{gr}$ & $483 \mathrm{gr}$ & $60 \mathrm{gr}$ \\
\hline 3 & $1000 \mathrm{gr}$ & $2400 \mathrm{rpm}$ & 10 menit & $450 \mathrm{gr}$ & $490 \mathrm{gr}$ & \\
\hline
\end{tabular}


210 Rancang Bangun Mesin Pengolah Jagung Untuk Pakan Ternak. Taufik kurniawan Mansur, Muh. Zultan, Hanasia, Abdul Salam, Luther Sonda

Tabel 4. Hasil pengujian batang jagung

\begin{tabular}{|c|l|c|c|c|c|c|}
\hline No & $\begin{array}{l}\text { Berat } \\
\text { Bahan }\end{array}$ & Kecepatan & $\begin{array}{c}\text { Waktu } \\
\text { pengolahan }\end{array}$ & $\begin{array}{c}\text { Berat Hasil } \\
\text { Pengolahan }\end{array}$ & $\begin{array}{c}\text { Berat sisa } \\
\text { yang } \\
\text { tertinggal }\end{array}$ & $\begin{array}{c}\text { Berat } \\
\text { yang } \\
\text { terbuang }\end{array}$ \\
\hline 1 & $1000 \mathrm{gr}$ & $2000 \mathrm{rpm}$ & 1 menit & $770 \mathrm{gr}$ & $200 \mathrm{gr}$ & $30 \mathrm{gr}$ \\
\hline 2 & $1000 \mathrm{gr}$ & $2200 \mathrm{rpm}$ & 1 menit & $850 \mathrm{gr}$ & $100 \mathrm{gr}$ & $50 \mathrm{gr}$ \\
\hline 3 & $1000 \mathrm{gr}$ & $2400 \mathrm{rpm}$ & 1 menit & $800 \mathrm{gr}$ & $80 \mathrm{gr}$ & $120 \mathrm{gr}$ \\
\hline
\end{tabular}

\section{HASIL DAN PEMBAHASAN}

Pada penentuan putaran motor dilakukan pengujian pada 3 kecepatan putaran mesin yang berbeda, yaitu pada putaran $2000 \mathrm{rpm}, 2200 \mathrm{rpm}$, dan $2400 \mathrm{rpm}$. Masing-masing kecepatan putaran mesin dilakukan 3 kali pengujian . Jadi total ada 12 pengujian pada tahap pengolahan pakan ternak.

Dari hasil pengujian yang telah dilakukan, maka kecepatan putar motor serta durasi untuk ketiga bahan diperoleh . Pertama, pengujian biji jagung pada saringan $6 \mathrm{~mm}$ digunakan kecepatan $2200 \mathrm{rpm}$ dengan durasi 4 menit, pada biji jaging yang menggunakan saringan diameter $3 \mathrm{~mm}$ dengan kecepatan putar $2400 \mathrm{rpm}$ dengan durasi 8 menit. Kedua, bonggol jagung menggunakan saringan diameter $3 \mathrm{~mm}$ dengan kecepatan putar $2200 \mathrm{rpm}$ memerlukan durasi 10 menit, dan pada batang jagung menggunakan saringan pengganti kecepatan $2200 \mathrm{rpm}$. Memerlukan durasi 1 menit. Dari ketiga pengujian di atas dapat di simpulkan bahwa untuk mendapatkan hasil pakan ternak yang berkualitas itu di tentukan oleh durasi sesuai jenis bahan (Biji, Bonggol dan Batang), besar diameter lubang saringan, plat pengganti saringan sebagai penutup dan kecepatan putaran motor.

Dari hasil pengujian alat yang telah di lakukan, mesin pengolah jagung untuk pakan ternak bisa menghasilkan pakan yang berkualitas untuk 1.000 gr biji jagung menggunakan saringan $\varnothing \mathbf{3 m}$ dengan kecepatan $2200 \mathrm{rpm}$ mendapatkan 412 gr biji jagung yang berkualitas, 36 gr yang terbuang dan 127 gr hasil halus

Pada biji jagung untuk 1.000 gr menggunakan saringan $\varnothing 3 \mathrm{~mm}$ dengan kecepatan $2.400 \mathrm{rpm}$ mendapatkan 412 gr biji jagung yang berkualitas, hasil halus 327 gr , buangan sisa yang masih belum terolah sempurna sebanyak 225 gram, sedangkan yang terbuang sebanyak 43 gr. (Gambar 3.1)

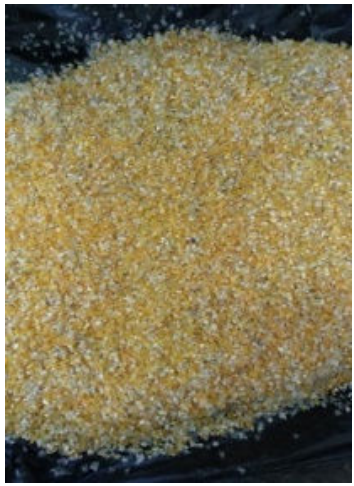

Hasil Saringan $\emptyset 3 \mathrm{~mm}$

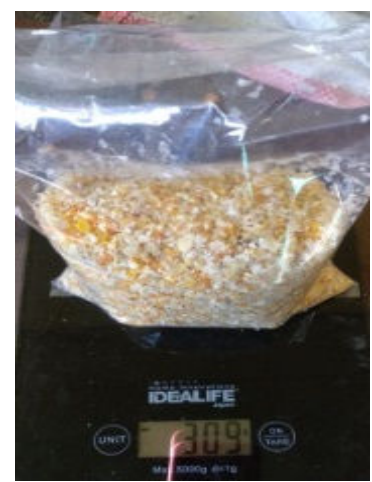

Hasil Kasar

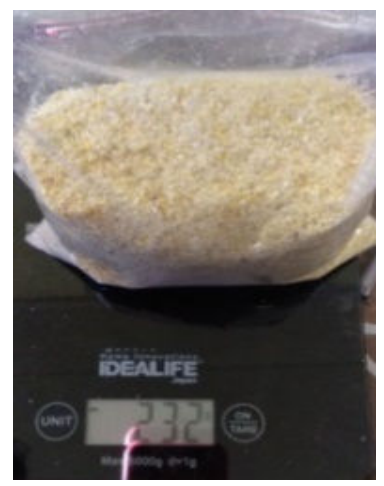

Hasil Halus

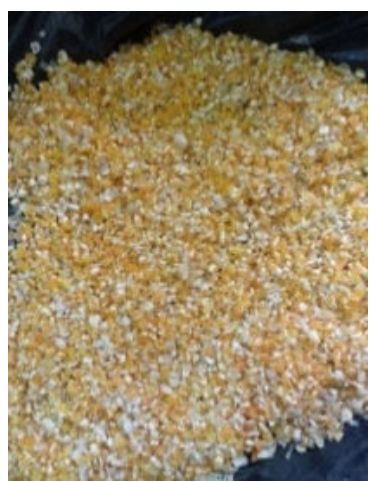

Buangan Sisa

Gambar 3.1 Hasil Pengujian Biji jagung dengan saringan $\emptyset 3$ mm

Pada biji jagung untuk 1.000 gr menggunakan saringan $\varnothing 6 \mathrm{~mm}$ dengan kecepatan $2200 \mathrm{rpm}$ mendapatkan 837 gr biji jagung yang berkualitas, 36 gr yang terbuang dan 127 gr hasil halus. (Gambar 3.2). 


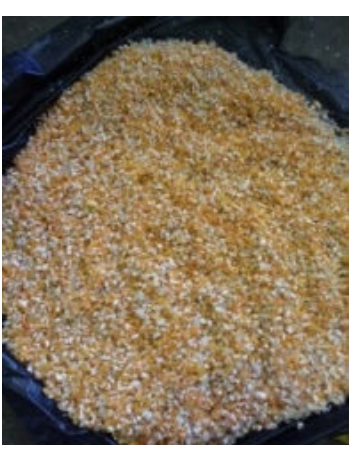

Hasil Saringan $\emptyset 6$ mm

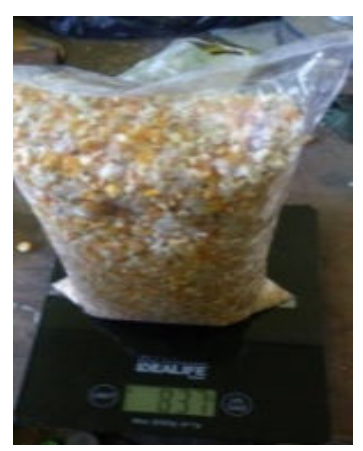

Hasil Kasar

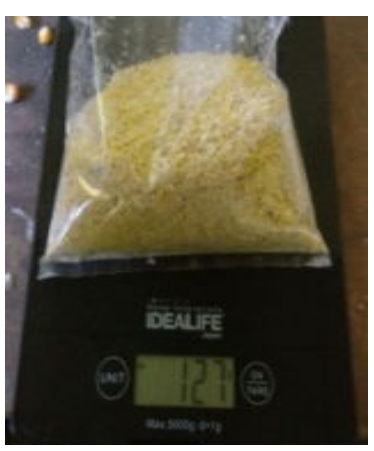

Hasil Halus

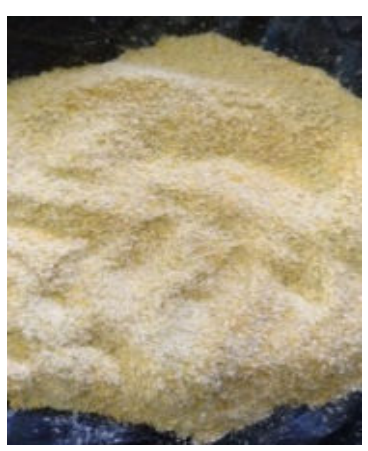

Buangan Sisa

\section{Gambar 3.2. Hasil Pengujian Biji jagung dengan saringan $\emptyset 6 \mathrm{~mm}$}

Pada bonggol jagung untuk 1000 gr menggunakan saringan $\emptyset 3 \mathrm{~mm}$ dengan kecepatan 2.200 rpm mendapatkan hasil sebanyak 483 gr bahan pakan ternak berkualitas, berat kasar sebanyak 477 gr dan yang terbuang 40 gr. (Gambar 3.3)

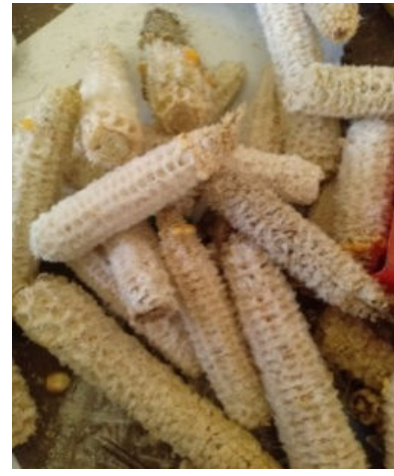

Sebelum Pengujian

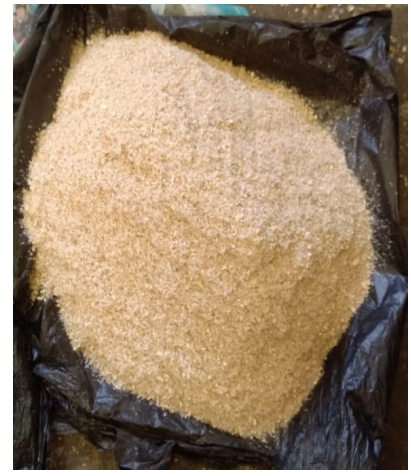

Hasil

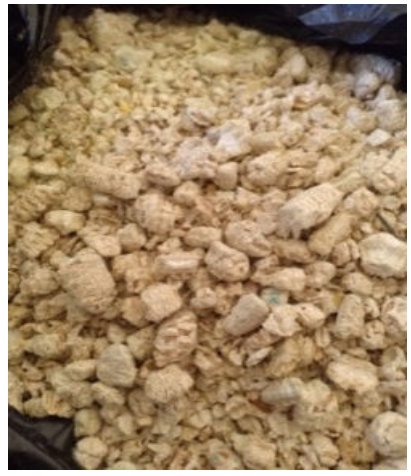

Buangan Sisa

\section{Gambar 3.3. Hasil Pengujian Bonggol jagung}

Pada batang jagung, untuk 1000 gr menggunakan plat pengganti saringan sebagai penutup dengan kecepatan $2200 \mathrm{rpm}$ mendapatkan 850 gr yang tercacah baik, sisa yang tertinggal $100 \mathrm{gr}$ dan berat yang terbuang 50 gr..

\section{KESIMPULAN}

Berdasarkan dari pembahasan diatas maka Rancang Bangun Mesin Pengolah Jagung Untuk Pakan Ternak ini penulis dapat mengambil beberapa kesimpulan sebagai berikut:

a. Dengan mesin ini, maka pakan ternak yang dihasilkan mencapai $15 \mathrm{~kg}$. Dari metode tradisional dengan hasil $5 \mathrm{~kg} / \mathrm{jam}$ menjadi $15 \mathrm{~kg} / \mathrm{jam}$. Sehingga mempermudah masyarakat dalam menghasilkan Pakan ternak

b. Meningkatkan kualitas produksi jagung untuk pakan ternak ayam dengan persentase pengolahan biji jagung $80 \%$, bonggol jagung $50 \%$, dan batang jagung/rumput jagung $80 \%$.

\section{UCAPAN TERIMA KASIH}

Penulis mengucapkan terima kasih kepada: 1). Pimpinan Politeknik Negeri Ujung Pandang atas dukungan yang diberikan, 2). Ketua, koordinator, sekretaris, dan staf Politeknik Negeri Ujung Pandang atas arahan dan kepercayaan yang diberikan, dan 3). Tim pelaksana rancang bangun atas kerjasamanya dalam menyelesaikan tugas akhir ini 
212 Rancang Bangun Mesin Pengolah Jagung Untuk Pakan Ternak. Taufik kurniawan Mansur, Muh. Zultan, Hanasia, Abdul Salam, Luther Sonda

\section{DAFTAR PUSTAKA}

[1] Azmi, P. (2019). Rancang bangun mesin pemecah biji jagung untuk pakan ternak sistem mekanik. Mataram: Universitas Muhammadiyah Mataram

[2] Fadillah dan Khairul Akbar. (2015). Pengaruh Pemberian Pupuk Fosfat dan Jarak Tanam Yang Tepat Terhadap Pertumbuhan dan Hasil Tanaman Jagung Manis (Zea mays Saccharata Sturt). Jurnal Penelitian Agrosamudra, 2(2), 71-81.Retrievedfrom. https:/ejurnalunsam.id/index.php/jagrs/article/view/326 (diakses 20 Januari 2020)

[3] Trisnadewi dkk. (2017). Kandungan Nutrisi Silase Jerami Jagung Melalui Fermentasi Pollard Dan Molases. Majalah Ilmiah Peternakan, $20(2), 55$. https://doi.org/10.24843/mip.2017.v20.i02.p03 Siwi, P. A. (2015). Bab ii tinjauan pustaka bakteri. 3-9.

[4] Kamus Besar Bahasa Indonesia (KBBI) Luar Jaringan (offline), Pusat Bahasa Kementrian Pendidikan Nasional. (20-01-2020)

[5] Sularso, dan Kiyokatsu Suga, 2008. Dasar Perancanaan dan Pemeliharaan Elemen Mesin ed13. Jakarta: Pradya Paramita 